\title{
EL RINCÓN DE LOS EDITORES
}

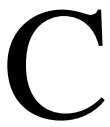

on el primer número del volumen 29 de Latin American Antiquity (LAQ) estamos muy contentos de poder anunciar buenas noticias para nuestros lectores y colaboradores. A partir de la edición de marzo 2018, el recuento anual de páginas de $L A Q$ se incrementará a 880, al igual que American Antiquity ( $A A Q)$. Hace solo dos años se le asignaron a $L A Q 576$ páginas, por lo que esto significa un aumento del 53\%, el mayor en la historia de la revista.

Como se explica en las notas editoriales de Jeremy Sabloff (1990, LAQ 1:2) y David Pendergast, el Consejo Directivo de la SAA creó $L A Q$ debido al reclamo de los miembros:

"All we ever see in American Antiquity is stuff about the Maya, the product of a mayanist cabal that is clearly plotting to take over the SAA itself!!!" So $[L A Q]$ was created, and the loathsome mayanist presence was expunged from [AAQ's] pages (Pendergast 1994, LAQ 5:191).

Estas notas editoriales dan a entender que algunos esperaban que la nueva revista fracasara. Así, originalmente, a $L A Q$ se le asignaron recursos muy limitados — tal vez debido a este prejuicio antimayista - a pesar de que a los suscriptores se les cobraba el mismo importe que por $A A Q$. Los viejos lectores recordarán que $L A Q$ se publicaba en pequeños panfletos verdes. El volumen 1 tenía solo 368 páginas, no mucho más que nuestro incremento actual.

Durante los siguientes 28 años, los sucesivos editores lucharon arduamente por un mayor número de páginas. Una razón importante es que las sumisiones han crecido dramáticamente. Desde hace cuatro años, cuando comenzamos nuestro tiempo como co-editores, las sumisiones anuales a $L A Q$ casi se han doblado. Durante los primeros siete años de esta década, la tasa de sumisión se ha triplicado (Rincón de los Editores, $L A Q$ 28:1). Durante los últimos dos años, $L A Q$ recibió tantas presentaciones como $A A Q$.

En la reunión de 2017, los miembros del Consejo Editorial de $L A Q$ aprobaron por unanimidad una moción de paridad con $A A Q$. Esta propuesta recibió un notable apoyo que incluyó una carta de muchos de los editores anteriores de la revista, quienes aún participan activamente en "the care and feeding of [LAQ]" (Pendergast 1994:191). El actual Consejo Directivo de la SAA respaldó con entusiasmo nuestra propuesta y un acuerdo con Cambridge University Press hizo realidad la paridad. Estamos agradecidos a todos nuestros socios, satisfechos de que se haya ganado la larga batalla por la igualdad y complacidos de que tres décadas de cuidado y sustento dieron lugar a una revista fuerte, próspera y en pleno desarrollo.

¿Qué significa esto? A partir de marzo, $L A Q$ publicará alrededor de diez artículos por número. Esto va a reducir sustancialmente el retraso acumulado, va a disminuir el tiempo desde el envío de los manuscritos hasta su publicación y nos permitirá aceptar un mayor número de los excelentes artículos que deseamos publicar. Así que, por favor ienvíen sus trabajos!

Recientemente hemos recibido numerosas presentaciones de dos áreas geográficas polarmente opuestas de América Latina: el Cono Sur de América del Sur y el noroeste de México. Con la ayuda de los sucesivos editores de nuestra revista hermana, $A A Q$, hemos construido un hermoso muro entre México y EE. UU., y $A A Q$ lo ha pagado. Como resultado, un mayor número de presentaciones sobre la arqueología de Sonora, Chihuahua y otros estados mexicanos está llegando a $L A Q$. El número actual contiene una sección especial con dos artículos sobre el noroeste de Mesoamérica y cuatro más sobre el norte de México, este último a menudo erróneamente y imperialísticamente llamado el "Suroeste".

Un gran avance ulterior, ya mencionado en nuestro último Rincón de los Editores, es la aprobación de una nueva guía de estilo para todas las revistas de la SAA. Si aún no la ha descargado y leído, le 
recomendamos que lo haga. Aunque la mayor parte de los cambios son menores, se fija un límite de 10.000 palabras para artículos y de 3.000 palabras para reportes. Tanto nosotros como nuestros sucesores en $L A Q$ no aceptaremos envíos que excedan dichos límites. Debemos aclarar que el máximo total de palabras no incluye el material suplementario. De hecho, alentamos a los autores a agregar información adicional (texto, figuras, tablas, entre otros) en la forma de material suplementario.

Habiendo alcanzado la paridad de páginas, nuestro principal objetivo como co-editores durante los años restantes en $L A Q$ es asegurarnos de que el contenido de la revista llegue a manos y computadoras de un mayor número de lectores en América Latina, preferiblemente de forma gratuita.

María Gutiérrez y Geoffrey E. Braswell

\section{EDITORS' CORNER}

$\mathrm{W}$ ith the first issue of Volume 29 of Latin American Antiquity (LAQ), we are very happy to have exciting news for readers and contributors. The annual page count of $L A Q$ has been increased to $880 \mathrm{pp}$., the same as our sister journal American Antiquity (AAQ). Just two years ago, $L A Q$ was allotted 576 pp., so this is a 53 percent increase, the biggest in the history of the journal.

The SAA Board of Directors originally created $L A Q$ because, as explained in editorials by Jeremy Sabloff (1990, LAQ 1:2) and David Pendergast, members cried out:

"All we ever see in American Antiquity is stuff about the Maya, the product of a mayanist cabal that is clearly plotting to take over the SAA itself!!!" So $[L A Q]$ was created, and the loathsome mayanist presence was expunged from [AAQ's] pages (Pendergast 1994, $L A Q$ 5:191).

At the start, $L A Q$ was allocated very limited resources - perhaps because of this anti-mayanist biaseven though subscribers were charged the same amount as for $A A Q$. Long-time readers will remember that $L A Q$ was once published in little green pamphlets. The four issues of Volume 1 had only 368 pp., not many more than our new increase.

Over the next 28 years, successive editors struggled mightily for more pages. One important reason is that submissions have grown dramatically. Since we began our editorship only four years ago, annual submissions have nearly doubled. During the first seven years of this decade, the submission rate has tripled (Editors' Corner, LAQ 28:1). For two years in a row, LAQ has had as many submissions as AAQ.

At our 2017 meeting, members of $L A Q$ 's Editorial Board unanimously passed a motion for parity with $A A Q$. This motion received extraordinary support, including a letter from many previous editors of the journal, who are still actively involved in "the care and feeding of [LAQ]" (Pendergast 1994:191). The current SAA Board of Directors enthusiastically endorsed our proposal, and an agreement with Cambridge University Press (CUP) has made parity a reality. We are grateful to all our partners, thankful that the long battle for equality has been won, and pleased that three decades of care and feeding have yielded a strapping, healthy, and full-grown journal.

What does this mean? Starting now, $L A Q$ will publish about ten articles and reports per issue, as well as more book reviews. This will substantially reduce the backlog, decrease time from submission to publication, and allow us to accept more of the excellent papers and reviews we wish to publish. So please submit!

Recent submissions from two polar-opposite areas of Latin America have been particularly numerous: the Southern Cone of South America and northwest Mexico. With the help of successive editors of our sister journal, we have built a beautiful wall between Mexico and the USA, and 
$A A Q$ has paid for it. As a result, many more submissions concerning the archaeology of Sonora, Chihuahua, and other Mexican states are coming to the editorial desk of $L A Q$. The current issue contains an exciting special section with two papers on northwest Mesoamerica and four more on northern Mexico, the latter often erroneously and jingoistically called the "Southwest."

A final development - already mentioned in our last Editors' Corner-is the approval of a new Style Guide for all SAA journals. If you have not yet downloaded and read it, we encourage you to do so. Although most changes are minor, it codifies limits of 10,000 words for articles and 3,000 words for reports. We-and our successors at $L A Q-$ will no longer send out for review submissions that exceed these limits. We hasten to add that these do not include online supplements; indeed, we encourage authors to place additional text, figures, tables, and other elements online.

Having now achieved page parity, our principal goals as co-editors for our remaining two years at $L A Q$ is to foster more publications in Spanish and to see that the content of your journal reaches the hands and computers of many more readers in Latin America, preferably for free.

Geoffrey E. Braswell and María Gutiérrez 